\title{
Introduction of Improved Okra (NHAe47-4) Variety as a Means of Economic Enhancement of Farmers in Ido Village, Ido Local Government Area, Oyo State, Nigeria
}

\section{*ADEBAYO, AS; AZEEZ, FA; ABEGUNRIN, OO; OGUNWALE, OG; OYEWOLE, OO; OJO, FF}

\author{
${ }^{*}$ Department of Agricultural Extension and Management, Federal College of Forestry, Ibadan. \\ *Corresponding Author Email: todedunmoye@yahoo.com, adekunleadebayo79@gmail.com; Tel: +2348033955697
}

\begin{abstract}
The study was carried out to introduce improved okra (NHAe47-4) variety to farmers in Ido Village in Ido Local Government of Oyo State using SAFE approach to agricultural extension which includes; capacity building among farmers to enable them diagnoses their problems, identify solutions and develop plans and implement them with or without support from outside. Farmers in the studied area were selected and a group was formed comprising of twelve (12) members. Sensitization and awareness creation were conducted in the study area through series of activities such as facilitating, interactive group discussions and several meetings with the farmers were held to orientate them of the improved okra variety through teaching and management techniques. Descriptive statistical tool such as frequency distribution and percentages was used to analyze the objectives. At the end of the harvesting and whole exercise, the group (farmers) was interviewed verbally to know their levels of awareness for adoption and their general view about the improved variety in relation to the normal okra variety they were used to. The farmers embraced the technology and they were actively participated through demonstration method exercise. Having known all the techniques involved in the production cycle, the farmers also tried the technology on their individual plot which served as an encouragement factor for adoption. The study thus resulted into improving the standard of living and economic enhancement of the farmers in the study area.
\end{abstract}

DOI: https://dx.doi.org/10.4314/jasem.v24i12.7

Copyright: Copyright (C) 2020 Adebayo et al. This is an open access article distributed under the Creative Commons Attribution License (CCL), which permits unrestricted use, distribution, and reproduction in any medium, provided the original work is properly cited.

Dates: Received: 22 October 2020; Revised: 28 November 2020; Accepted: 09 December 2020

Keywords: Okra, varieties, economic enhancement, farmers, Ido village

Okra Abelmoschus esculentus (L.) Moench, is an annual crop. The crop requires warm growing condition and it is found in almost every market all over Africa (Schippers, 2000). It originated from Asia and Africa and it is an important vegetable grown in tropical and subtropical parts of the World (Absar and Siddique, 1992). It grows best in a well-drained and fertile soil. The plant bears numerous dark green coloured pods measuring about $5-15 \mathrm{~cm}$ in length and takes about 45-60 days to bear fruits ready for harvest. In Nigeria, okra production is predominantly carried out by peasant farmers and it is among the foremost vegetable crops, in terms of consumption and production area (Iremiren and Okiy, 1999).The economic importance of okra is very enormous. Okra contains carbohydrate, protein and vitamin $\mathrm{C}$ in large quantities (Adeboye and Oputa, 1996). The essential and non- essential amino acids that okra contains are comparable to that of soyabean, therefore, the consumption of okra plays an important role in human nutrition. Nigeria with a population of about 150 million people and an exponential population growth rate of $2.52 \%$ (World Bank, 2011), is likely to face a challenge of population explosion. This situation is capable of translating into more unemployment and poverty. Thus, it is necessary to develop the agricultural sector to provide employment and thereby alleviate poverty. One aspect of the sector is vegetable production, which contributes to the nutritional value and improving the standard of living of farmers. The yield of okra in Nigeria is very low (about 2 tons $/ \mathrm{ha}^{-1}$ ) (Adenana, 1985). Among the factors that could result in low yield include unimproved local cultivars commonly grown and scanty stands. Yayock (1979) suggested that one of the important ways of increasing the economic yield of most crops is by cropping in high density as well as using improved varieties. Adeniji (2003) in previous study on performance of different varieties of West African okra observed that improved and serial varieties produce high yield. Series of research work on okra has been conducted at National Horticultural Research Institute (NIHORT) Ibadan and Institute for Agricultural Research (IAR), Ahmadu Bello University, Samaru Zaria, where much emphasis on agronomy and physiology performance improvement programme has made little progress due 
to the fact that okra continues to be regarded as a marginal crop. As a result of socio- economic importance of okra as a vegetable, its production has rapidly increased in recent years. Therefore, different varieties were used by farmers in order to meet the demand of okra by consumers.

NHAe 47-4 okra variety has different response on a given soil and season with high quality yield. Modern agriculture requires that farmers use scientific knowledge. In Nigeria a lot of scientific knowledge to improve agricultural production is available. But the problems today faced by farmers are not using this scientific knowledge. Farmers' major problem is the dependence on the use of local or traditional varieties that gives very low yield and poor in protein quality. Thus, this has led to the introduction of high yielding improved variety of okra (NHAe 47-4) to the farmers in Ido village in Ido Local Government Area of Oyo State.

The introduction of NHAe 47-4 variety is to help farmers to improve and increase okra production in the study area. Thereby increasing their income, improve their standard of living and meet the demand of the consumers. The objective of this study is to introduce improved okra variety (NHAe 47-4) to farmers in Ido village of Ido Local Government Area of Oyo State, Nigeria

\section{MATERIALS AND METHODS}

The study was carried out at Ido local government area of Oyo State, with headquarter at Ido town. The local government area shares boundaries with other Local Government Areas such as Oluyole, Akinyele, Ibarapa East, Ibarapa North West, Ibarapa South West of Oyo State and Odeda local government in South of Ogun State. The entire area is located in the forest region of Nigeria. The study area experiences two seasons (wet and dry) which allows the practice of both dry season and rainfed cropping. Crops grown include fruits, vegetables, maize, cassava, yam, and plantain at various times of the year. Ido local government area of Oyo State occupies a total land mass of about eight hundred square kilometres (800sq.km) and the population is fifty two thousand, five hundred and eighty two $(52,582)$ people (NPC 2006). The major occupation of the people in the area is farming, while alongside other vocational jobs, food vendors, livestock farming being practiced. Ido local government area of Oyo State is suitable for data collection, because it reflects a geographical representation of the State where traditional agriculture is predominant as a primary occupation. Data were collected from primary and secondary sources.
The following were methods used in data collection: 1. Use of verbal interview and administering questionnaire to farmers; 2. Collective participation.

Descriptive statistics such as percentage and frequency distribution was used to analyse the data. A target group of twenty (20) farmers was formed in consultation with the opinion leaders that was selected purposively within the study area. This group later remained twelve (12) volunteered farmers who were actively participating majorly in okra production which made up of twelve (12) men. These farmers were introduced to the production of NHAe 47-4 and its agronomy. The study was not an experimental, but an action research; therefore, there was no designed method of experiment but only a layout of farm that involved farmers in all aspect. The techniques employed includes, group formation, demonstration plot and training including awareness campaign.

Demonstration plots: A demonstration plot was established which belong to the whole group in which all learning processes took place at a layout of $10 \mathrm{~m} \mathrm{x}$ $15 \mathrm{~m}$ dimension.

The use of demonstration plot has enhanced the extensive uses of their senses and skills, as well improved their knowledge on agronomy activities of NHAe 47-4 okra variety.

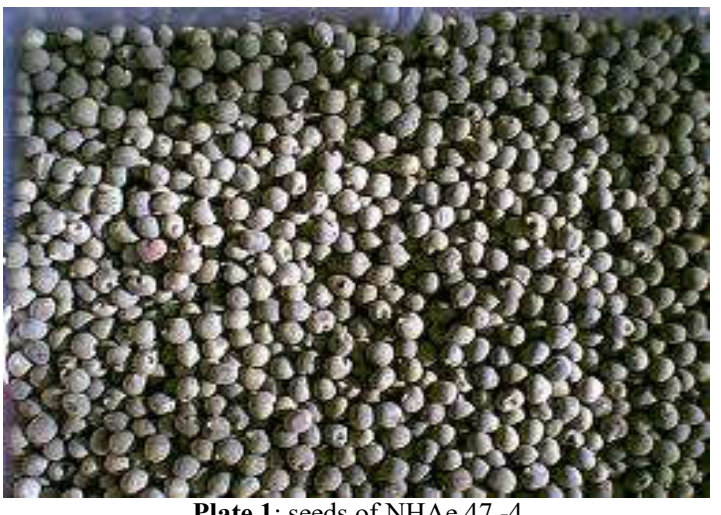

Plate 1: seeds of NHAe $47-4$

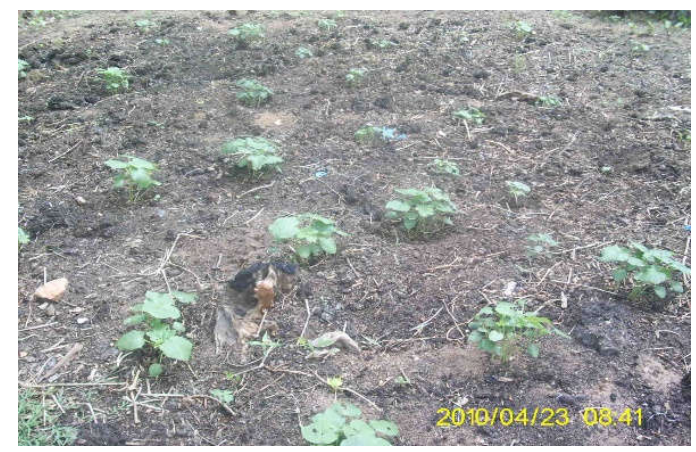

Plate 2: Two weeks after planting (2WAP) 


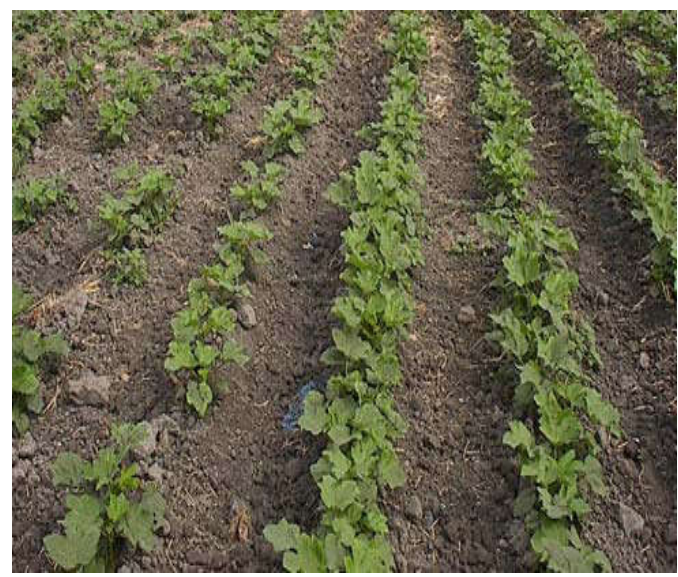

Plate 3: Four weeks after planting (4WAP)

\section{RESULTS AND DISCUSSION}

Socio-economic Characteristics of the Respondents: This distribution shows that the average age of the sampled farmers was about 35 years constituting about $58.33 \%$ and this implies that most of the farmers were at their youth stage. This indicated that younger farmers are more likely to adopt the technology than older/aged farmers because of better education and exposure to new ideas. The results supported the observation reported by Aktas (1973) that the age of farmers contributes to the adoption of new technologies. The tables 1 and 2 shows the distribution of the respondents according to their gender. It shows that the sampled farmers were both males and females. About $91.67 \%$ of the respondents were males while $8.33 \%$ were female.

Table 1: Distribution of Respondents by Age

\begin{tabular}{lll}
\hline Age limit & Frequency & (\%) Distribution \\
\hline $20-30$ & - & 0.00 \\
$31-40$ & 7 & 58.33 \\
$41-50$ & 4 & 33.33 \\
$51-60$ & 1 & 8.33 \\
61 above & - & 0.00 \\
Total & 12 & 100 \\
\hline
\end{tabular}

Table 2: Distribution of Respondents According to Gender

\begin{tabular}{lll}
\hline Gender & Frequency & (\%) Distribution \\
\hline Male & 11 & 91.67 \\
Female & 1 & 8.33 \\
Total & 12 & 100 \\
\hline
\end{tabular}

Table 3: Distribution of Respondents According to Marital Status

\begin{tabular}{lll}
\hline Marital Status & Frequency & $\mathbf{( \% )}$ Distribution \\
\hline Married & 10 & 83.33 \\
Not married & 02 & 16.67 \\
Total & 12 & 100 \\
\hline
\end{tabular}

The findings indicated that males are more in vegetable production in the study area, while women are actively participating in marketing. The table 3 shows that $83.33 \%$ of the respondents were married while about $16.67 \%$ were single. This is in agreement with the findings of Adebayo, A.S et al (2019) who postulated that $88.2 \%$ of the farmers were married; this may be due to the fact that married people have more responsibilities and participation in agriculture would improve their standard of living. Table 4 shows that $8.33 \%$ of the respondents attended Quaranic education, $16.67 \%$ attained primary school, $58.33 \%$ of the respondents' attained secondary school, $0 \%$ attained post graduate level and only $16.67 \%$ attained university degree. The results supported that of Knight's (2000) findings, where he stated that the household level of education affected the timing of adoption of new technology in Ethiopia.

Table 4: Distribution of Respondents According to Educational

\begin{tabular}{llc}
\multicolumn{2}{c}{ Status } \\
\hline Education Status & Frequency & (\%) Distribution \\
\hline Quranic Education & 01 & 8.33 \\
Primary School & 02 & 16.67 \\
Secondary School & 07 & 58.33 \\
University Degree & 02 & 16.67 \\
Post Graduate & - & - \\
Total & 12 & 100 \\
\hline
\end{tabular}

Table 5 shows that, household size ranging from (0-5) had $66.67 \%,(6-10)$ had $25 \%,(11-15)$ and (16-20) had $0 \%$ and none had $8.33 \%$. This result shows that the household size of the sampled farmers affected the adoption of NHAe 47-4 technology. This finding supported the observation reported by Just and Zilberman (1985), that when the number of the nonworking adult is greater than the working adult, technology adoption is affected negatively. Table 6 shows that about $41.67 \%$ had farming experience between two to three years (2-3yrs) and 25\% farmers having farming experience between one to two years. While three to four years and four to five years were $16.67 \%$ respectively. This result supported what was obtained by Aktas (1973). Who pointed out that the farming experience affected the rate of technologies adoption. Table 7 shows that $8.33 \%$ of the respondents devoted 0.5 -1 ha of the farmland to okra production, $25 \%$ devoted 0.5 ha, and only $0 \%$ devoted $1.5-2 \mathrm{ha}$, while $66.67 \%$ accounted for others of the total farm land for okra production. This result shows that the total farmland of the respondents could affects the speed of NHAe 47-4 okra adoption and it agrees with the result of Manfield (1968) who reported that the total farmland contributes to technologies adoption.

Table 5: Distribution of Respondents According to Household

\begin{tabular}{lll}
\multicolumn{2}{c}{ Size } \\
\hline Household Size & Frequency & (\%) Distribution \\
$0-5$ & 08 & 66.67 \\
$6-10$ & 03 & 25.00 \\
$11-15$ & - & - \\
$16-20$ & - & - \\
None & 1 & 8.33 \\
Total & 12 & 100 \\
\hline
\end{tabular}


Table 6: Distribution of Respondents According to Year of Farming Experience

\begin{tabular}{lll}
\hline $\begin{array}{l}\text { Year of Farming } \\
\text { Experience }\end{array}$ & Frequency & (\%) Distribution \\
\hline $1-2$ & 03 & 25.00 \\
$2-3$ & 05 & 41.67 \\
$3-4$ & 02 & 16.67 \\
$4-5$ & 02 & 16.67 \\
5 above & - & - \\
Total & 12 & 100 \\
\hline
\end{tabular}

Table 7: Distribution of Respondents According to Farmland devoted to okra Production

\begin{tabular}{lll}
\hline Farmland for Okra & Frequency & (\%) Distribution \\
\hline $0.5 \mathrm{ha}$ & 03 & 25.00 \\
$0.5-1 \mathrm{ha}$ & 01 & 8.33 \\
$1-1.5 \mathrm{ha}$ & - & - \\
Others & 08 & 66.67 \\
Total & 12 & 100 \\
\hline
\end{tabular}

The table shows that about $66.67 \%$ of the respondents travelled $0.5-1 \mathrm{~km}$ from their farmland to the accessible road. Only $33.33 \%$ of the respondents travelled $1.5-2 \mathrm{~km}$ from their farms to the accessible road. This implies that their farms are readily accessible to road for easy transportation.

The table below shows that $58.33 \%$ of the respondents employed family labour in farming activities, while $25 \%$ of the respondents employed both family and hired labour in their farms, and only $16.67 \%$ of the respondents used only hired labour on their farms. Most farmers obtain their income to faster their farming activities from other sources. Trading constitutes about $33.33 \%$, salary workers constitute $25 \%$, while $41.67 \%$ constitute others.

This result shows that the farmers' income affected the rate of adoption in the study area and it agrees with the findings of Ruttan and Thirtle (1987). Feder el al; 1985, who postulated that access to credit enhanced the adoption of new technologies. The non-adopters were unable to adopt the technology because they don't have any good source of income and this has been a problem to adoption speed.

Table 11 shows that only $16.67 \%$ of the respondents have access to credit and about $83.33 \%$ do not have access to credit and this has affected the adoption rate negatively in terms of the intensity of adoption, thereby reducing the agricultural production in the study area.

Table 8: Distribution of Respondents According to the Distance of Farmland to the Accessible Road

\begin{tabular}{lll}
\hline Distance (Km) & Frequency & (\%) Distribution \\
\hline $0.5-1$ & 8 & 66.67 \\
$1.5-2$ & 4 & 33.33 \\
Total & 12 & 100 \\
\hline
\end{tabular}

Table 9: Distribution of Respondents According to Labour Employed on the Farm

\begin{tabular}{lll}
\hline Types of Labour & Frequency & (\%) Distribution \\
\hline Family & 07 & 58.33 \\
Hired & 02 & 16.67 \\
Family and Hired & 03 & 25.00 \\
Total & 12 & 100 \\
\hline
\end{tabular}

Table 10: Distribution of Respondents According to Source of

\begin{tabular}{lll}
\multicolumn{3}{c}{ Income } \\
\hline Source of Income & Frequency & (\%) Distribution \\
\hline Trading & 04 & 33.33 \\
Salary worker & 03 & 25.00 \\
Other & 05 & 41.67 \\
Total & 12 & 100 \\
\hline
\end{tabular}

Table 11: Distribution of Respondents According to Access to Credit Facilities

\begin{tabular}{|c|c|c|}
\hline Access to Credit & Frequency & (\%) Distribution \\
\hline Those who have & 02 & 16.67 \\
\hline Those who don't have & 10 & 83.33 \\
\hline Total & 12 & 100 \\
\hline
\end{tabular}

From Table 12 it can be deduced that $75 \%$ of the vegetable farmers within the community made use of improved okra variety, while $25 \%$ still go by the local variety due to their low source/ financial income which prevented them from obtaining necessary input. Table 13 shows that $50.00 \%$ of the respondents adopted NHAe 47-4 okra because of its high yield, $41.67 \%$ adopted it because of rapid growth, while $8.33 \%$ did not adopt the variety for the reason best known to them.

Table 12: Distribution of Respondents that used other improved seed before NHAe47-4

\begin{tabular}{lll}
\hline Adoption & Frequency & $\mathbf{( \% )}$ Distribution \\
\hline Adopted & 09 & 75.00 \\
Non adopted & 03 & 25.00 \\
Total & 12 & 100 \\
\hline
\end{tabular}

Table 13: Distribution of Respondents According to Reasons for Adopting NHAe 47-4 okra variety

\begin{tabular}{lll}
\multicolumn{3}{c}{ Adopting NHAe 47-4 okra variety } \\
\hline Reasons & Frequency & $\begin{array}{l}\text { (\%) } \\
\text { Distribution }\end{array}$ \\
\hline Resistance to diseases and & - & - \\
pests & & \\
Low fertilizer requirement & - & - \\
Rapid growth & 5 & 41.67 \\
Better yield & 6 & 50.00 \\
Non adopter & 1 & 8.33 \\
Total & 12 & 100 \\
\hline
\end{tabular}

Table 14 revealed the reaction of farmers after seeing the results of the demonstrations in terms of yields obtained. This was a result of the strict observance of the recommended practices demonstrated as follows:

- Land clearing - After clearing the demonstration plot, farmers went into clearing their own fields to prove the demonstrator's recommendation.

- $\quad$ Ridging - The recommended form of making ridges was accepted, compared to formal way of 
making their ridges for planting which made some operations difficult to be carried out for effective output.

- $\quad$ Improved seed - They used their local varieties, which was affordable but discovered that the yield of improved okra was higher.

- $\quad$ Seed treatment - Farmers discovered that treated seeds had about $100 \%$ germination with vigour unlike their varieties, which gave about $65 \%-70 \%$ germination with less vigour and requires planting supplementation.

- $\quad$ Planting time - it was recommended that planting should be done at appropriate time so as to reduce infestation of diseases.

- $\quad$ Seed rate - farmers discovered that, their seed rate per hole was too much and so resolved to be using recommended seed rate.

- $\quad$ Plant spacing - Close spacing was believed to give crowded plant population and reduced the size of the okra pods, therefore recommended spacing was adopted.

- $\quad$ Weeding - it was recommended that weeding should be done regularly to avoid nutrient competition between the crops and weeds.

- Use of herbicide - the group had known the use of herbicide on the field for clearing grasses before cultivation. This helps to add more nutrient into the soil as nothing is burnt or packed before ridges were made.

Table 14: Level of adoption of recommended practices

\begin{tabular}{lll}
\hline Reasons & Frequency & $\mathbf{( \% ) ~ D i s t r i b u t i o n ~}$ \\
\hline Land clearing & 12 & 100 \\
Ridging & 12 & 100 \\
Use of improved seed & 12 & 100 \\
Seed treatment & 12 & 100 \\
Planting date & 12 & 100 \\
Seed rate & 12 & 100 \\
Plant spacing & 12 & 100 \\
Fertilizer application & 12 & 100 \\
weeding & 12 & 100 \\
Use of herbicide & 12 & 100 \\
Total & 12 & 100 \\
\hline
\end{tabular}

Awareness of NHAe 47-4 okra: After the completion of this project, all group members were interested in the variety and were extended to the entire farmers in the village and most the farmers became aware of the variety due to its value and other superiorities such as early maturity and high yield. Others are production practices.

Group management and strengthening: After the whole exercise, though the farmers group have been practicing the use of communal effort in their farming activities, the group had more cohesion for continuity and management even though they are not registered. For consistency and effective management, the group selected their leader for proper coordination to avoid failure and to achieve desired results. They are also aware of the importance of forming group as it is the easiest way to have linkage with government agencies on agriculture.

Record keeping in the group: At the end of the project, record keeping by the student has helped taught the farmers' group of proper record keeping of activities. The result showed that good record keeping will help them to:

- Compare their previous and present activities.

- Determine their total expenditures, profit and loss within a cropping season.

- $\quad$ Determine worthiness of the group if seeking for loan.

- $\quad$ Shows the role of members of the group.

- $\quad$ Reference for feature use by members in the method of practices.

Correct Use of fertilizer: The group now knows the correct fertilizer to use at the appropriate time and the dosage with the method of application.

Table 15 shows that all members of the group (100\%) agreed that NHAe 47-4 okra variety is early maturing than other variety that they were used to as compared by the number of days to maturity.

Table 15: NHAe 47-4 Okra farmers that indicated early maturity

\begin{tabular}{lll}
\hline & Frequency & $\mathbf{( \% )}$ Distribution \\
\hline Late maturing & - & - \\
Early maturing & 12 & 100 \\
Total & 12 & 100 \\
\hline
\end{tabular}

Conclusion: Generally, it was observed that before the introduction of the innovation of NHAe47-4 okra variety to farmers within the community, Ido Village, the farmers have been working through the use of communal efforts in executing their farming programmes which made the formation of group on NHAe47-4 variety easy. The effective use of recommended agronomic practices with good crop performance will go a long way in ensuring high yield per unit area. In view of this, continuous sensitization, awareness creation, group formation and regular field days will help in enhancing the use of the technology adoption among the vegetable (okra) farmers in the study area.

\section{REFERENCES}

Adebayo, A.S; Adedeji, M.S; Adams, O.T; Majebi, O.E (2019). Willingness to establish private forest plantation among dwellers in some selected local government area of Osun State, Nigeria. Journal 
of Research in forestry, wildlife and environment, Vol. (11)3, Pp 6

Adesina, A.A; Baid-Forson, J (1995). "Farmers" Perception and Adoption of New Agricultural Technology, Evidence from Analysis in Burkina Faso and Guinea, West Africa. Journal of Agricultural Economics, Vol.13, Pp.1-9.

Aktas M. (1973). "A study on Information Sources, Agricultural Extension Methods and Other factors affecting adoption of chemical fertilizer in cotton production in Antalya Province, Ankara. Pp56

Caswell, M; Fuglie, K; Ingram, C; Jans, S; Kascak, C (2001). "Adoption of Agricultural Production Practices: Lessons Learned from the US Department of Agriculture area studies project". Washington Dc. Us Department of Agriculture. Resource Economics Division, Economic Research Service, Agricultural Economics Report. No. 792.

Concley; Udry (2002). Learning About New Technology: Principle in Ghana, Unpublished paper. Yale University, Economic growth centre, centre discussion paper Pp. 49

Ehler, L.E; Bottrell, D.G (2000). "The Illusion of Integrated Pest Management. Issues in Science and Technology". Bell and Howell Information and Learning Company, Pp. 61-64

Feder, G; Slade, R. (1982). "The Acquisition of Information and the Adoption of New Technologies" American Journal of Agricultural Economics, Vol. (66)3, Pp 312-320.

Gutkind; Zilberman (1985). Adoption of Improved Fallow Technology for Soil Fertility Management in Zambia: Emperical Studies and Emerging Issues" Agroforestry System 59: Pp. 317-326
Griliches; Mansfield (1961). "The Adoption of Innovations: the Neglected role of institutional constraints. Mimeograph Department of Rural Sociology. The Ohio State University Columbus, Ohio.

International Food Policy Research Institute (IFPRI), (1998). "Pest Management and Food Production". Looking into the future (2)52, 46.

Just; Zilberman (1985). "Adoption of Sustainable Agricultural Practices: Diffusion, Farm Structure and Profitability" Journal of Rural Sociology, Vol. (59)2, Pp. 333-349.

Rogers, E.M; Shoemaker, M; Peterson (1985). "Communication of Innovations" The Free Press, New York. Pp 42

Rogers E.M., Shoemaker; Runguist (1984). "Population Growth and the Adoption of New Technology in Taiwaness Agriculture" Working Paper, No. 6. Columbia, MO: University of Missouri

Ruttan; T (1987). "Technology Adoption in the Present Constraints: the case of fertilizer demand in Ethiopia" Rev. Dev. Econ. 7(1), 58-70.

Weir, A; Knight J. (2000). “Adoption and Diffusion of Agricultural Innovations in Ethiopia: the role of education". (SAE Working Paper WPS2000-5, Centre for the Study of African Economics, Oxford University. Uk. 